\title{
LABOUR MARKET TRENDS IN LATVIA
}

Laura Joma ${ }^{1}$, lecturer/ Mg.paed; Simona Zvirgzdina², lecturer/ Mg.proj.mgmt. Latvia University of Life Sciences and Technologies

\begin{abstract}
The labour market is the most important resource in the business environment. The employee is one of the main resources, the quality of which is the one that determines the quality of the company's goods and service. Twofold information is heard in Latvia: state institutions point out that labour market trends are only improving, but entrepreneurs point out that there is a lack of a quality and motivated workforce. In the publicly available information, one can find indications that labour market indicators are improving, there are increasing average wages and decreasing unemployment rates. The article analyses the criteria that have the most impact on labour market trends. Each year the population of Latvia is decreasing, which can cause serious problems in nearest future and in the distant future radical problems for all.
\end{abstract}

Key words: employees, employer, migration, labour market.

JEL code: J01, JO8.

\section{Introduction}

Based on Central Statistical Bureau of Latvia (CSB), the number of employees in Latvia from 2012 till 2018 increased from $54.4 \%$ to $65.3 \%$, and also unemployment rate reduced from $16.3 \%$ to $7 \%$. At the same time, entrepreneurs are discussing that high qualification employees are hard to find. In the last six years, population rate has decreased from 2.1 million in 2010 to 1.9 million in 2018. Also, in 2013 the number of higher education graduates was 26057, but 2017 it was just 18354. All these numbers show that labour market rates are higher not just because employees can easier find jobs, but the number of employees is decreasing. Those employees who have jobs or are searching for new jobs with higher wage, can increase their demands for entrepreneurs. So, it leads to decreasing working quality, artificially increasing salaries and the demand for high qualified employees. The negative demographic trends, a corresponding shortage of labour in the future can be important barrier to economic growth. A key prerequisite for stabilizing labour supply is for changing demographic trends: the long-term gap between new-born and dead numbers must be bridged, while in the medium term, the labour market failures can be offset by a prudent migration policy.

For these reasons, the research aim is to describe labour market supply and demand for employee competencies and labour market trends in Latvia if, hypothetically, labour market trends depend on the population.

The research tasks were : 1) to describe and explain labour market trends; 2) to describe and explain differences of labour market demand for employees in different industries; 3 ) to describe migration impact on labour market supply of employees.

The research object is labour market. The present research was based on monographic method, statistical analysis, abstract and logical analyses.

\section{Research results and discussion}

\section{Labour market trends in Latvia}

Labour market trends in Latvia depend on the number of working population. According to the statistics, only $55 \%$ of all working population in Latvia were defined as employees, $7.1 \%$ were pupils and students and $3.6 \%$ were temporarily disabled and permanently disabled persons. The number of growing selfemployed and unpaid family workers is slowly growing, which can be explained by the trend, that people want to work for themselves and do not want to depend on someone else.

\footnotetext{
${ }^{1}$ Laura Joma: laura.joma@llu.Iv 
The trend of increasing non-working pensioners number is also slowly growing. Authors think that it depends on employers: younger employers are searching for younger and higher qualified employees, but employers with long experience are using also working capability of pensioners, because they have longer work experience and thus they could teach skills from their experience, which universities and colleges can't give to students. That is a very valuable opportunity, which is not used by every employer.

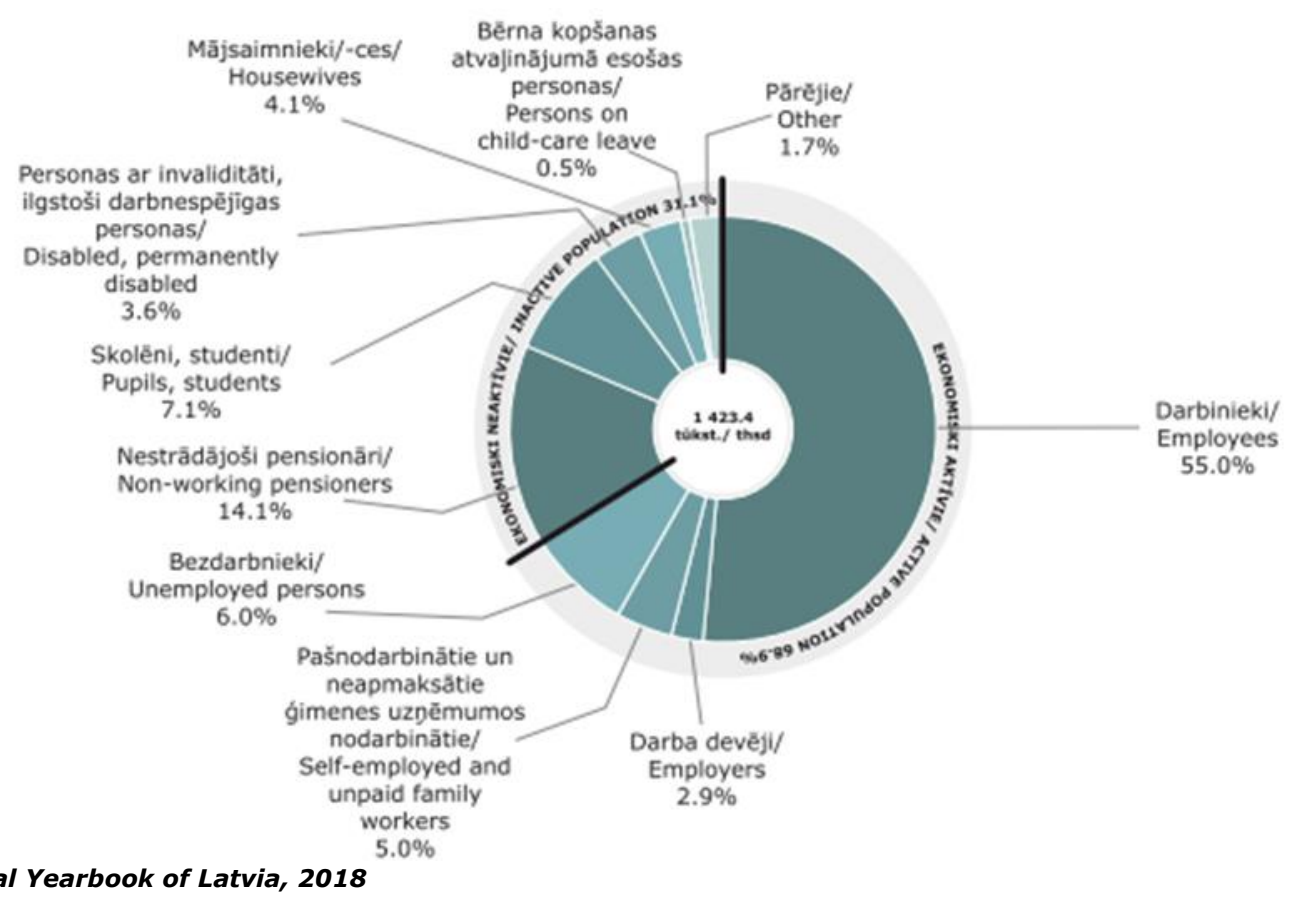

Fig. 1. Labour status of population aged 15-74 in Latvia 2017

The results of the Labour Force Survey conducted by the Central Statistical Bureau show that 920.1 thousand people or $65.3 \%$ of Latvia's population aged 15-74 (incl.) were employed in the 3rd quarter of 2018. Over the year, employment rate grew by 1.7 percentage points and number of employed persons by 17.2 thousand. Compared to the previous quarter, employment rate grew by 0.9 percentage points and number of employed persons increased by 10.5 thousand (In the $3^{\text {rd }}$ quarter..., 2018).

According to the medium - and long-term forecasts of the Ministry of Economic Affairs, the labour market situation will continue to improve gradually in the coming years - by 2022 the number of employees will increase by around 50 thousand, while the unemployment rate will fall to $6 \%$ (Labour market medium, 2016).

In the $3^{\text {rd }}$ quarter of 2018 , the employment rate among young people (aged 15-24) constituted $36.2 \%$, which is 1.3 percentage points higher than in the corresponding period of 2017 . Out of all young people, 62.7 thousand were employed (In the $3^{\text {rd }}$ quarter..., 2018).

Results of the Labour Force Survey conducted by the Central Statistical Bureau show that in the $3^{\text {rd }}$ quarter of 2018 Latvian unemployment rate constituted $7.0 \%$. Compared to the previous quarter, unemployment rate fell by 0.7 percentage points, while during the year it decreased by 1.5 percentage points (In the $3^{\text {rd }}$ quarter..., 2018). 
20

15

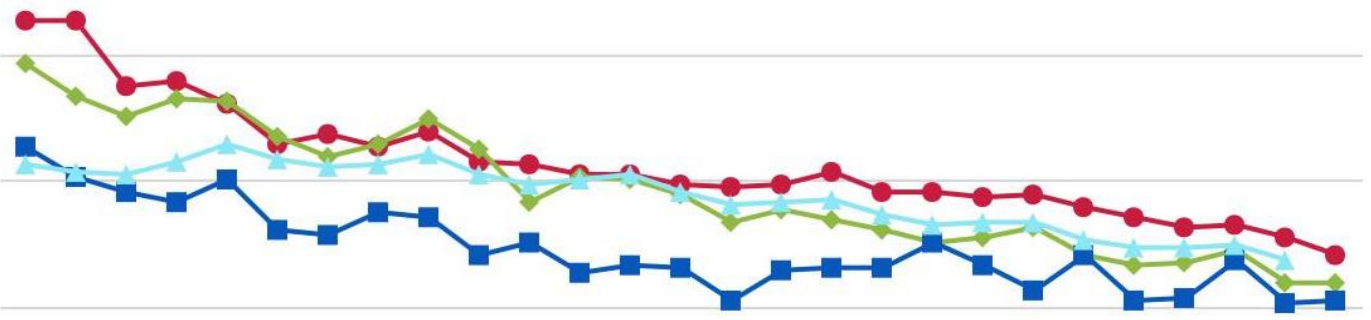

5

0

Source: Eurostat database, Labour Force Surveys of Latvia, Lithuania and Estonia

Fig. 2. Unemployment rate in the Baltic states and the European Union by quarter, as per cent

In the $3^{\text {rd }}$ quarter, in Latvia there were 68.8 thousand unemployed persons aged 15-74 (incl.), which is 15.3 thousand people less than a year ago and 6.6 thousand people less than in the previous quarter (In the $3^{\text {rd }}$ quarter..., 2018).

In 2015, Latvia changed the rules for the application of Unemployment Benefit. Until 2015, if a person had worked at least 12 months, he or she had unemployment benefit in $80 \%$ of his six months' average wage, but after the changes in the law, the person can get just $50 \%$ of one's average wage. Just those who had worked at least 30 years can apply for unemployment benefit in $65 \%$ of average wage.

This is just one of the aspects that have also influenced unemployment rate in Latvia. The authors have observed that many people before applying for unemployment benefit, are hesitating if they need it or not, because the unemployment benefit is too low for their usual standard of living, they don ' $t$ want to go to different employers for job search and also they are ashamed for the status of unemployed. Meanwhile, they are searching for different opportunities to work, and thus if they can 't get jobs, they apply for status, in parallel working without contract of employment, thus getting paid by government and employer at the same time.

Table 1

Europe 2020 headline indicator - Employment, EU-28, 2008 and 2012 - 2016

\begin{tabular}{|c|c|c|c|c|c|c|c|c|}
\hline Topic & Headline indicator & 2008 & 2012 & 2013 & 2014 & 2015 & 2016 & Target \\
\hline \multirow{3}{*}{ Employment } & $\begin{array}{l}\text { Employment rate age group 20-64, } \\
\text { total ( } \% \text { of population) }\end{array}$ & 70.3 & 68.4 & 68.4 & 69.2 & 70.1 & 71.1 & 75.0 \\
\hline & $\begin{array}{l}\text { - Employment rate age group 20-64, } \\
\text { females (\% of population) }\end{array}$ & 62.8 & 62.4 & 62.6 & 63.5 & 64.3 & 65.3 & : \\
\hline & $\begin{array}{l}\text { - Employment rate age group } 20-64, \\
\text { males (\% of the population) }\end{array}$ & 77.8 & 74.6 & 74.3 & 75.0 & 75.9 & 76.9 & \\
\hline
\end{tabular}

Source: Smarter, greener, more..., 2017

According to Europe 2020, in 2016 the Member States had commitment to reach employment of $75 \%$ of population, but in Latvia it is just $65.3 \%$, which means, that Latvia still needs to change many different norms not just in entrepreneurial environment but also in regulatory enactments. Moreover, there is a need to take cardinal actions to increase the population of Latvia, because, based on the current statistics, there is a risk that in the future Latvian population can become extinct as a nation. 


\section{Labour market demand and supply for employees in different industries}

Form 19 industries, just in six industries the wage is higher than the average salary in the overall country. If we compare the number of people who are working in these six industries basing on CSB data base, then in 2017 just 167.8 thousand of 894.0 thousand employees had higher than average wage in country, and in 2018 just 158.3 thousand of 905.7 thousand employees could be included in this group. So, it means that $81 \%$ of employees in 2017 and $82 \%$ of all employees in Latvia in 2018 received the average wage or salary in the particular industry, which generally was lower than the average salary in the overall country.

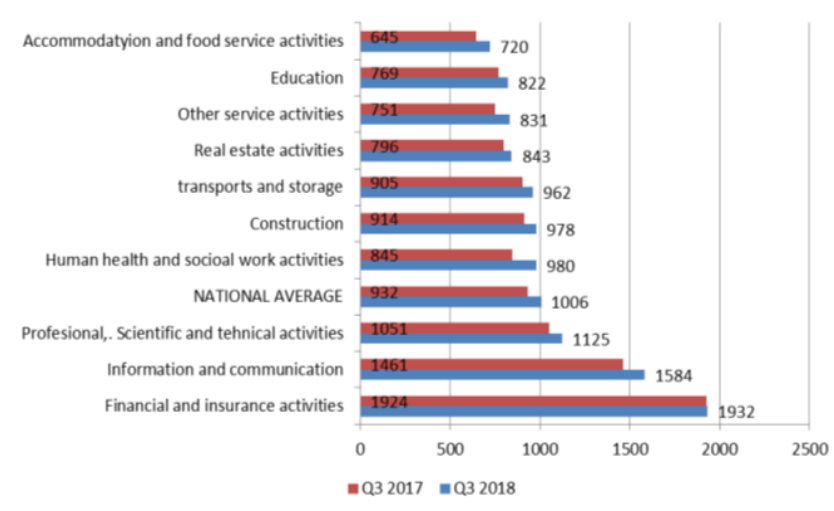

Source: In the 3rd quarter..., 2018

Fig. 3. Average monthly gross wages and salaries in Q3 2017 and Q3 2018 and changes thereof

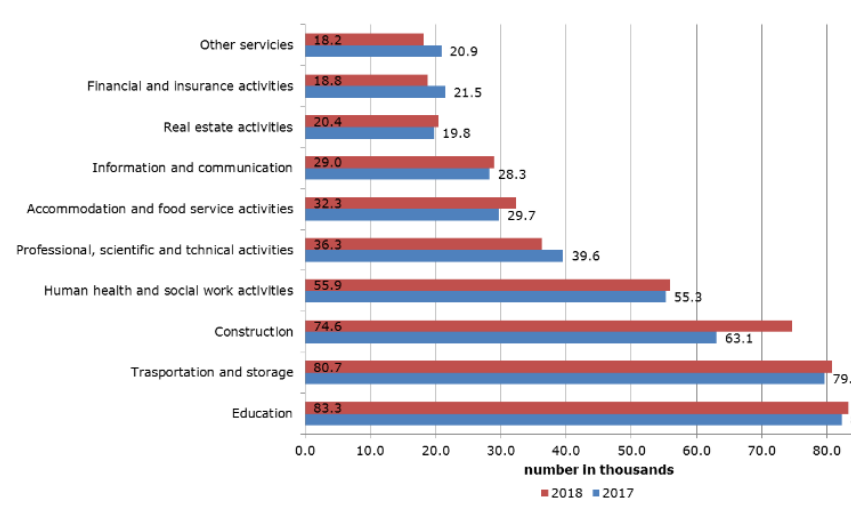

Source: CSB statistics, 2018

Fig. 4 Employees in Latvia by type of economic activity in 2017 and 2018 , thousand 
In the $3^{\text {rd }}$ quarter of 2018 , the highest wages and salaries for full-time work were registered in financial and insurance activities, information and communication, energy, public administration and defence, mining and quarrying, as well as professional, scientific and technical activities. In other sectors, the average wages and salaries before taxes were below the national average (In the $3^{\text {rd }}$ quarter..., 2018).

The lowest wages and salaries, in turn, were observed in accommodation and food service activities, education, other service activities (that includes activities of public and other organisations, repair of computers and personal and household goods, washing and (dry-) cleaning, hairdressing and other beauty treatment, funeral and related activities), real estate activities, as well as arts, entertainment and recreation (In the 3rd quarter..., 2018).

The State Employment Agency, which is responsible for compiling the statistical data of job vacations in the country, has claimed that at this moment the most needed jobs are in such specialities as technicians and associate professionals, service and sales workers, craft and related trade workers, elementary occupations. Considering, tad people can earn salary that is under average salary in the country and consumer price index in last 2 years have increased from 101.7 to 106.4, more people choose higher-paid jobs, and lighter and lower paid jobs are only selected in extreme need.

Jobs in financial and insurance activities, information and communication, energy, public administration and defence, mining and quarrying are not the ones where many advertisements can be found. These are sectors in which there are very many candidates in the case of vacancies, but they lack the qualifications or competence to carry out the jobs in question. Therefore, in these sectors, entrepreneurs are prepared to pay high salaries for employees, with a high degree of professionalism, responsibility and competence in the performance of the tasks entrusted.

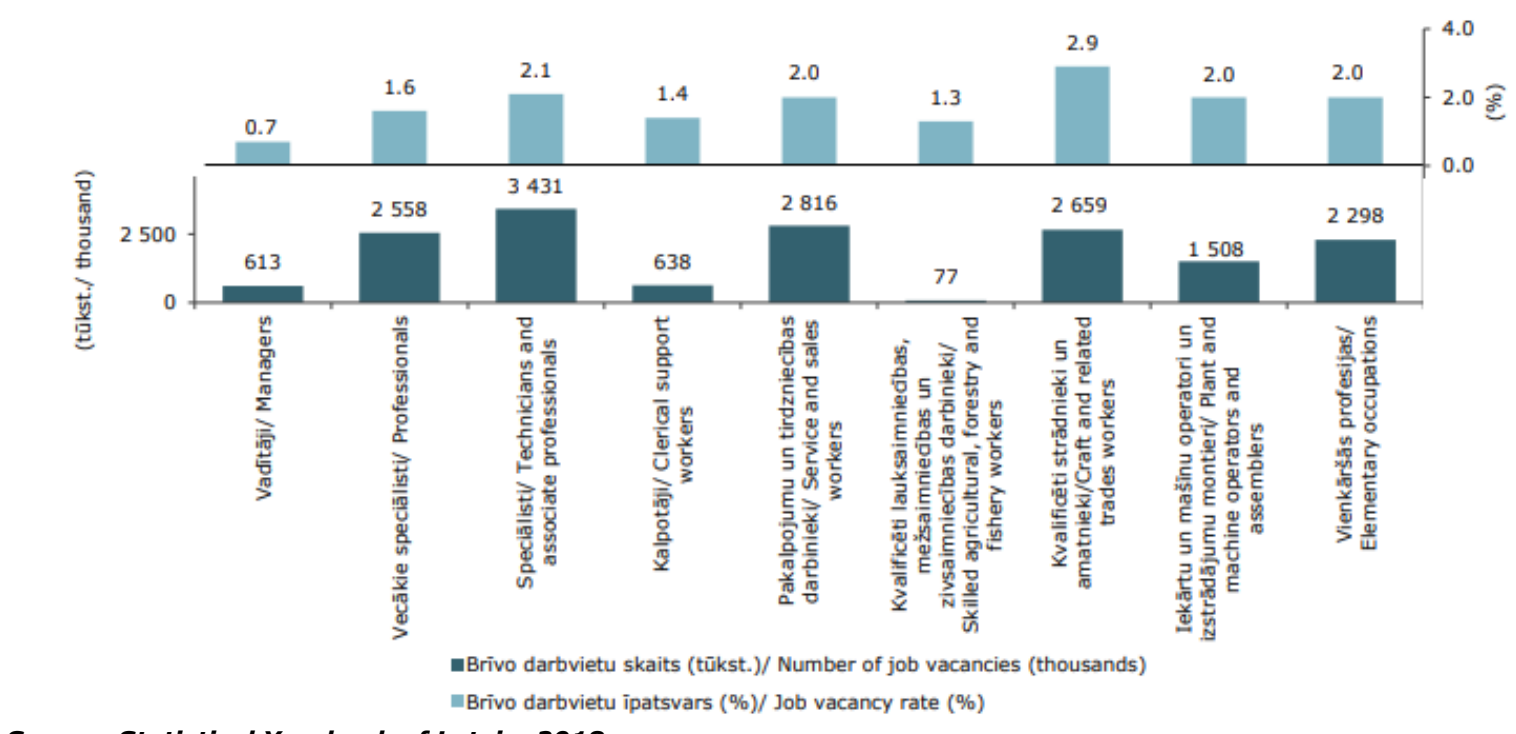

Source: Statistical Yearbook of Latvia, 2018

Fig. 5. Annual average number of job vacancies by major occupational grouping, 2017

In view of the lack of skilled labour in the labour market, employers are, as far as possible, supporting education institutions, technical education, job schools and higher education institutions, providing students with places of practice, the environment for research and, as far as possible, grants to the best students. 


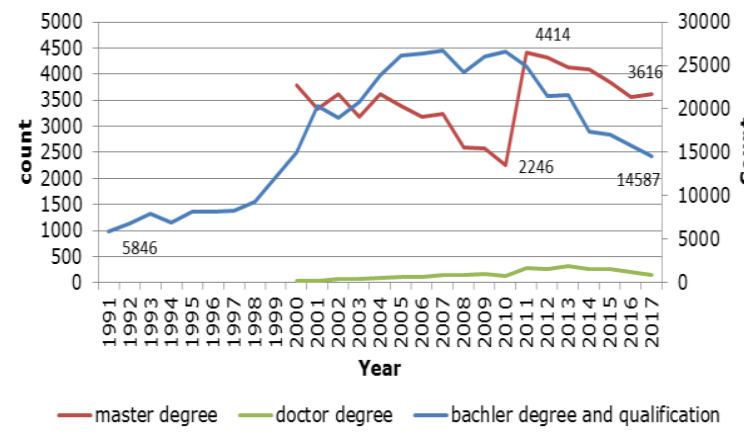

Source: Ministry of Education..., 2017

Fig. 6. Number of students graduating in Latvia in 1991-2017

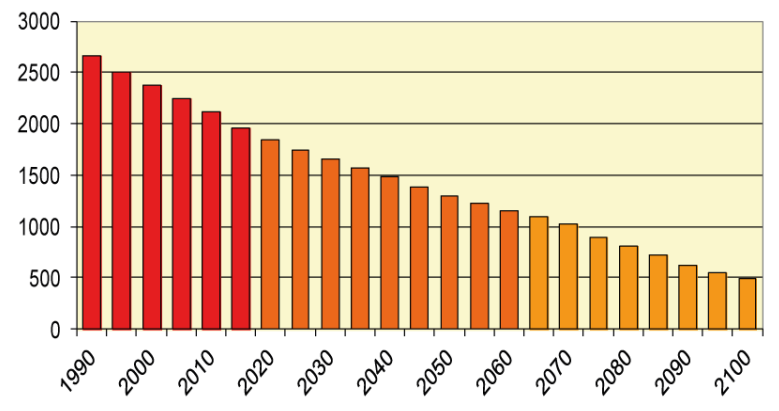

Source: Helmane I., 2017

Fig. 7. Decrease in Latvia's population (thousands) in 1990-2010 and forecasts by $\mathbf{2 1 0 0}$ without immigration

However, in view of the shrinking population in Latvia and the shrinking number of students at the different levels of education, it is concluded that the shortage of skilled labour will only increase in the coming years, which will create further problems in the labour market, both in terms of wage policy in companies and in the performance of quality work and in the labour market as a whole.

According to the report of the head of the International Migration Organization's Riga office Ilmars Mezs, $t$ problems in Latvia could arise due to both the age structure and the numerical composition of the population. "In terms of sustainability, it will be very difficult with human resources. In the future economy, the problem will be the high proportion of seniors and the relatively small number of working people," explained demographer. „If now, by very approximate estimates, there are two workers per retiree, then with time that ratio will be 1:1" (Helmane I., 2017).

The optimistic forecast of Eurostat, assessing the decline in Latvia's population from 1990 to 2010 and forecasts by 2100 , predicts that in 2050 Latvia will have a population of around 1.3 or 1.4 million, but after 83 years, if potential immigration is not taken into account, 500000 people will live in our country alone. Mathematically estimated, the number will decrease by around 18,000 inhabitants each year (Helmane I., 2017).

\section{Migration impact on labour market supply of employees}

The optimistic forecast of Eurostat, assessing the decline in Latvia's population from 1990 to 2010 and forecasts by 2100 , predicts that in 2050 Latvia will have a population of around 1.3 or 1.4 million, but after 83 years, if potential immigration is not taken into account, only 500000 people will live in our country. The mathematical estimates suggest that the population will decrease by around 18000 each year (Helmane I., 2017).

The professor's findings suggest that the average share of vacancies in all professions currently is $1.6 \%$ (14 445 jobs), which is slightly lower than the EU average of $1.8 \%$. Therefore, the situation on the labour market could not be judged to be extremely severe. This is also reflected in a survey by the Central Statistical Bureau, in which only $14 \%$ of manufacturing operators replied that labour shortages were a problematic factor (Helmane I., 2017).

Moreover, statistics show that there are No shortages of professionals in one particular profession, but different types of professionals, both with good education and simple professionals. When compared by sector, high vacancy rates, above $4 \%$, are in public administration, air transport and the manufacture of computers, electronic and optical equipment. In particular, there is a shortage of veterinary service providers, with a vacancy rate of $12.5 \%$ (Helmane I., 2017). 
Source: Map of migration... source? www.....

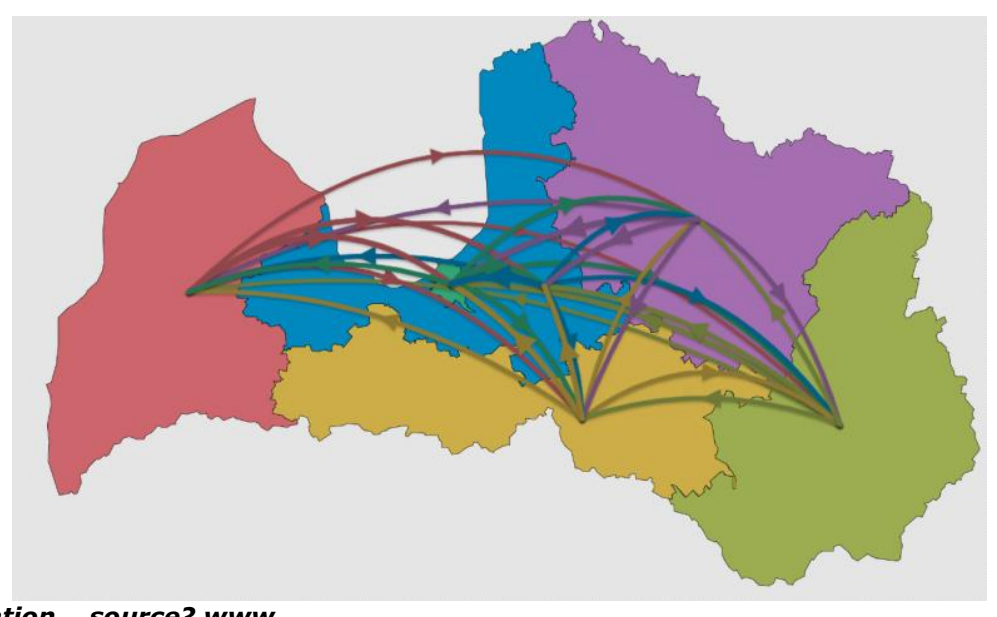

Fig. 8. Map of migration in Latvia 2000-2018

Between 2000 and 2018, the population changes are $-24 \%$, with $7.5 \%$ remaining in other regions. In Zemgale, the population changes are $-20.9 \%$, while $10.8 \%$ have travelled to other regions. Latgale has a population change of $-30.0 \%$, with $6.9 \%$ leaving for other regions. Vidzeme has a population change of $-25.9 \%$, with $11.5 \%$ leaving. In Pierga, the population changes are $1.5 \%$, with $12.4 \%$ left in other regions. In Riga, the population changes are $-16.4 \%$, with $9.7 \%$ left in other regions.

The largest number of emigrations is from Pierga to Riga 31206. For example, there are 16572 emigrating persons from Latgale to Riga during this period.

From 2000 to 2018, the migration flows are mostly to or from Riga. For the purposes of this map, the origin/destination of the migration flow is mainly the cities of the republic significance.

The data from the CSB also show that the population in Pierga is increasing. In the view of the regions, the population annually increased only in Pierga, i.e. by 2300 inhabitants or $0.6 \%$. According to the CSB, the main cause of the increase is internal migration, but the indicator of natural movement in Pierga has been positive during the last three years(We are even..., 2018).

The largest decrease in population is still seen in Latgale - by 5400 or $2.0 \%$, however it is $0.3 \%$ less than in 2016. Meanwhile, the population in Vidzeme has decreased by 3300 (1.7\%), also in Kurzeme it decreased by 3300 (1.3\%), in Zemgale - by 2700 (1.1\%) and in Riga - by 3500 $(0.5 \%)$. In the analysed period, one third or $33 \%$ of Latvian residents lived in Riga (We are even..., 2018).

The CSB points out that the population has fallen in seven of the nine cities of the republic. Positive figures were in Jurmala in 2017, with population growth of $1.0 \%$ or 467 people and $0.4 \%$ or 102 in Valmiera. The population decreased most in Ventspils - by $1.4 \%$ or 507 people, in Daugavpils - by $1.6 \%$ (1342), in Jekabpils - by $1.0 \%$ (224), while the least - in Rezekne - by $0.1 \%$ (18) (We are even..., 2018).

Instead of migrating abroad, Latvian residents of working age will continue to migrate from rural areas to cities, particularly to Riga and Riga region, where there are opportunities for higher wages and opportunities for more professional growth. However, it is expected that a higher GDP growth rate - around $5 \%$ - and a $50 \%$ lower income gap between Riga/Pierga and regions could slow Latvia's internal migration (Demographic Portrait of..., 2017). 


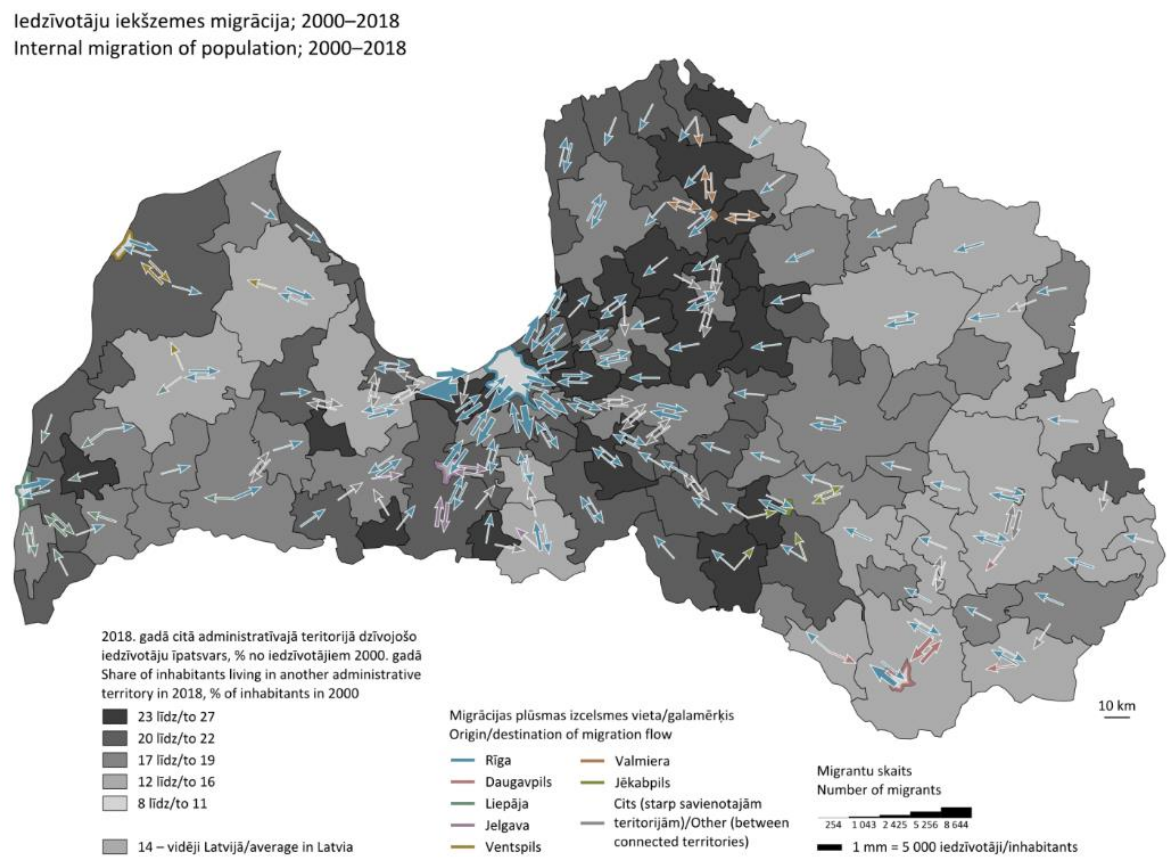

Source: Internal migration of..., 2018

Fig. 9. Internal migration of population in 2000-2018

For domestic migration, it is important to understand the motives for resettlement. The main reason is mostly aspiration to improve personal living conditions. Therefore, the change of residence is linked to job search or education, finding a cheaper place of residence, purchasing a dwelling or reasons related to the environment of life. Accordingly, the migration to cities in Latvia is linked to population's activity in the labour market and to the extensive educational opportunities in the cities. In contrast, suburban movements are linked to people's desire to improve housing conditions and to live in a quieter and more attractive environment, or closer to nature. In this context, highly geographic mobility in Latvia is typical for young people who go to learn and seek better work, followed by higher levels of education and better professional qualifications in line with the needs of the labour market.

\section{Conclusions, proposals, recommendations}

1) Publicly available information suggests that the statistic of the labour market development are comply with the real situation in Latvia. However, the statistics reflecting the number of employees in particular industries of the labour market does not reflect the real situation in Latvia. Moreover, as much as $82 \%$ of all employees in Latvia receive less than average wage in country.

2) Employers' demand for employees with higher education, higher qualification and competencies is increasing, thus employers are ready to pay higher wage than currently offered in Latvia, so employees in financial and insurance activities, information and communication, energy, public administration and defence, mining and quarrying industries receive the wage that is higher than the average wage in Latvia. In these industries there are many people who want to get jobs in these industries and can demand higher salary for their qualifications and competencies.

3) According to the migration analysis, one can observe that the cities which are far from Riga have less population than in Riga and Pieriga. Rural regions are getting less inhabited, because youth 
are searching for jobs with higher wages and opportunities, and only those young people whose parents started their own business in home-places like farms are continuing the family business.

\section{Bibliography}

1. CSB statistics (2018). Retrieved: https://data1.csb.gov.Iv/pxweb/Iv/sociala/sociala_nodarb_nodarb_ikgad/NBG081.px. Access: 20.02.2019.

2. Darba tirgus videja un ilgtermina prognozes (Labor market medium and long term forecasts) (2016). Retrieved: https://www.em.gov.Iv/lv/aktuali/10556-darba-tirgus-videja-un-ilgtermina-prognozes. Access: 04.02.2019.

3. Helmane, I. (2017). Latvija 2100. gada varetu but vien pusmiljons iedzivotaju (In Latvia in 2100 could be only half a million population). Retrieved: https://lvportals.Iv/norises/286795-latvija-2100-gada-varetu-butvien-pusmiljons-iedzivotaju-2017. Access: 22.02.2019.

4. In the 3rd quarter of 2018, Latvia's Employment Rate Constituted $65.3 \%$ (2018). Retrieved: https://www.csb.gov.Iv/en/statistics/statistics-by-theme/social-conditions/unemployment/search-intheme/2423-employment-3rd-quarter-2018. Access: 04.02.2019.

5. In the 3rd quarter of 2018, Latvia's Unemployment Rate Constituted $7.0 \%$ (2018). Retrieved: https://www.csb.gov.lv/en/statistics/statistics-by-theme/social-conditions/unemployment/search-intheme/2427-unemployment-3rd-quarter-2018. Access: 04.02.2019.

6. In the 3rd quarter, Average Earnings Constituted EUR 1006 (2018). https://www.csb.gov.Iv/en/statistics/statistics-by-theme/social-conditions/wages/search-in-theme/2386changes-wages-and-salaries-3rd-quarter-2018. Access: 20.02.2019.

7. Internal Migration of Population; 2000-2018 (2018). Retrieved:https://www.csb.gov.Iv/en/statistics/statistics-by-theme/population/migration/search-intheme/367-internal-migration-population-2000-2018. Access: 20.02.2019.

8. Latvijas demografiskais portrets sodien ...un rit (Demographic Portrait of Latvia today... and tomorrow) (2017). Retrieved: http://certusdomnica.Iv/wpcontent/uploads/2017/05/Certus_LatvijasDemografiskaisPortrets_2017_LV-1.pdf. Access: 20.02.2019.

9. Latvijas statistikas gadagramata, 2018 (Statistical Yearbook of Latvia 2018) Retrieved: https://www.csb.gov.Iv/sites/default/files/publication/201812/Nr_01_Latvijas_statistikas_gadagramata_2018_Statistical \%20Yearbook \%20of \%20Latvia_\%2818_00 \%29_LV_EN.pdf. Access: 04.02.2019.

10. Map of Migration in Latvia 2000-2018. Retrieved: https://migracija.csb.gov.Iv./ Access: 20.02.2019.

11. Ministry of Education and Science (2017). PARSKATS par Latvijas augstako izglitibu 2017.gada (REPORT about Higher Education in Latvia in 2017). Retrieved: https://www.izm.gov.Iv/images/statistika/augst_izgl/AII_2017_parskats.pdf. Access: 20.02.2019.

12. Musu ir vel mazak. Publice jaunakos datus par iedzivotaju skaitu Latvija (We are even less. Publish the latest data on population numbers in Latvia ) (2018). Retrieved: http://www.la.Iv/musu-ir-vel-mazakpublice-jaunakos-datus-par-iedzivotaju-skaitu-latvija Access: 20.02.2019.

13.Smarter, Greener, More Inclusive? INDICATORS TO SUPPORT THE EUROPE 2020 STRATEGY (2017). Retrieved: https://ec.europa.eu/eurostat/documents/3217494/8113874/KS-EZ-17-001-ENN.pdf/c810af1c-0980-4a3b-bfdd-f6aa4d8a004e. Access: 06.02.2019. 